\title{
Thermococcus aegaeicus sp. nov. and Staphylothermus hellenicus sp. nov., two novel hyperthermophilic archaea isolated from geothermally heated vents off Palaeochori Bay, Milos, Greece
}

\author{
Hocine Arab, Horst Völker and Michael Thomm
}

Author for correspondence: Michael Thomm. Tel: +49431880 4330. Fax: +494318802194.

Institut für Allgemeine Mikrobiologie, Christian Albrechts Universität zu Kiel, Universität Kiel, Am Botanischen Garten 1-9, 24118 Kiel, Germany

\begin{abstract}
Two novel, hyperthermophilic, anaerobic, heterotrophic archaea were isolated from shallow hydrothermal vents off Palaeochori Bay, Milos, Greece. Strain P5 ${ }^{\top}$ (BK17S6-3-b2') is an irregular coccus, with a single polar flagellum, growing optimally at $90{ }^{\circ} \mathrm{C}$, pH 6 and $2 \% \mathrm{NaCl}$. The DNA G+C content was $45 \mathrm{~mol} \%$. Due to its morphology, phylogenetic analyses based on 16S rRNA gene sequencing, DNA-DNA hybridization experiments, physiological properties and nutritional features, this strain represents a new species within the genus Thermococcus for which the name Thermococcus aegaeicus is proposed. The type strain is P5 $^{\top}$

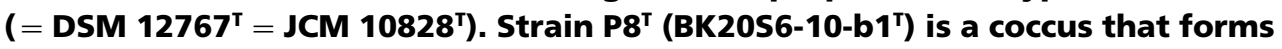
aggregates. It grew optimally at $85{ }^{\circ} \mathrm{C}$, pH 6 and $3 \% \mathrm{NaCl}$. The DNA G+C content was $38 \mathrm{~mol} \%$. Physiological properties and sequence analysis of the 16S rRNA gene, as well as DNA-DNA hybridization experiments, indicate that this strain is a new species belonging to the genus Staphylothermus for which the name Staphylothermus hellenicus is proposed. The type strain is $\mathrm{P8}^{\mathrm{T}}$ ( = DSM ${ }^{12710^{\top}}=$ JCM 10830').
\end{abstract}

Keywords: hyperthermophiles, Aegean Sea, Thermococcus, Staphylothermus, hydrothermal vents

\section{INTRODUCTION}

More than 20 different genera of hyperthermophilic archaea have been isolated from geothermal and hydrothermal environments (Stetter, 1996). These micro-organisms are a valuable source for the exploitation of novel biotechnological processes and provide unique models for the investigation of principles of thermoadaptation.

The hyperthermophilic archaea appear to occupy the deepest branches of various phylogenetic trees (Stetter, 1996). Hyperthermophiles are normally isolated from areas undergoing vigorous hydrothermal activity and they are subjected to various geochemical challenges (Gonzalez et al., 1998). Consequently, marine hydrothermal vents are normally colonized by hyper-

The GenBank accession numbers for the 16S rRNA sequences of Thermococcus aegaeicus strain $\mathrm{P}^{\top}$ and Staphylothermus hellenicus strain $\mathrm{PB}^{\top}$ are AJ012643 and AJ012645, respectively. thermophilic strains representing diverse physiological types (Jannasch et al., 1992).

In the Aegean Sea, venting of hot water has been described in the Caldera of Santorini (Holm, 1987; Varnavas et al., 1990) and off the coast of Kos and Yali (Varnavas \& Cronan, 1991). Furthermore, hydrothermal activity has been detected at several areas around the island of Milos as reported by Dando et al. (1995). The genus Stetteria has been isolated from marine sediments at Palaeochori Bay in Milos (Jochimsen et al., 1997), but otherwise the diversity and ecological role of archaea in Aegean hot vent systems are unexplored. In this study we report the isolation and characterization of two novel hyperthermophilic archaea from hydrothermal vents off Palaeochori Bay near the island of Milos, Greece.

\section{METHODS}

Sample collection. Samples of marine sediment were collected from a shallow water area (K1 site at 4-5 m depth and 
W1 site at $9.5 \mathrm{~m}$ depth) during a fieldtrip to Palaeochori Bay (Milos, Greece; 14-29 September 1996). The sediment temperature at this area was between 90 and $103{ }^{\circ} \mathrm{C}$. The samples were placed into $100 \mathrm{ml}$ screw cap bottles, reduced with sodium sulfide at a final concentration of $0.05 \%$ and then stored at $4{ }^{\circ} \mathrm{C}$ for further analyses.

Reference strains. Staphylothermus marinus (DSM 3639), Pyrococcus furiosus (DSM 3638), Pyrococcus woesei (DSM 3773), Thermococcus celer (DSM 2476) and Pyrodictium occultum (DSM 2709) were obtained from the DSMZ (Deutsche Sammlung von Mikroorganismen und Zellkulturen, Braunschweig, Germany).

Enrichment, isolation and cultivation. For the enrichment, $20 \mathrm{ml}$ half-strength SME medium (Stetter et al., 1983) supplemented with $2 \%$ elemental sulfur in $120 \mathrm{ml}$ serum bottles (type III glass; Bormioli) was inoculated with $1 \mathrm{ml}$ marine sediment and incubated without shaking at $90{ }^{\circ} \mathrm{C}$ in a $\mathrm{H}_{2} / \mathrm{CO}_{2}$ atmosphere $(80: 20, \mathrm{v} / \mathrm{v} ; 300 \mathrm{kPa})$. For the isolation of pure cultures, the enrichment cultures were plated on the same medium solidified with $1 \%(\mathrm{w} / \mathrm{v})$ Phytagel (Sigma) and 2-3\% (w/v) sodium alginate (Roth) according to the method of Kovacs \& Rakhely (1996). The Petri dishes were incubated in pressurized stainless steel cylinders at $90^{\circ} \mathrm{C}$ (Balch et al., 1979). Positive colonies were then transferred into liquid medium and incubated at $90{ }^{\circ} \mathrm{C}$. Thereafter, the cultivated strains were stored at $4{ }^{\circ} \mathrm{C}$ for further investigations.

Large-scale cultivation was performed in a 1001 enamelcoated fermenter (Braun Biotech International) in halfstrength SME medium containing $0 \cdot 25 \mathrm{~g}$ sulfur $1^{-1}$. The stirring rate was 150 r.p.m. for the cultivation of $\mathrm{P}^{\mathrm{T}}$ and 100 r.p.m. for $\mathrm{P}^{\mathrm{T}}$. The gassing rate at the beginning of the fermentation was $0 \cdot 81 \mathrm{H}_{2} / 0 \cdot 21 \mathrm{CO}_{2} \mathrm{~min}^{-1}$ for $\mathrm{P}^{\mathrm{T}}$ and 0.751 $\mathrm{H}_{2} / 0.31 \mathrm{CO}_{2} \mathrm{~min}^{-1}$ for $\mathrm{P}^{\mathrm{T}}$. When the cells entered the exponential growth phase, the gassing rate was increased for both strains to $4.01 \mathrm{H}_{2} / 1 \cdot 01 \mathrm{CO}_{2} \mathrm{~min}^{-1}$. Simultaneously, the stirring rate was increased to 300 r.p.m. (P5 $\left.{ }^{\mathrm{T}}\right)$ or 350 r.p.m. $\left(\mathrm{P} 8^{\mathrm{T}}\right)$.

Light microscopy. Cells were mounted on agar-coated slides and photographs were taken on Kodak plus-X-pan film with a Zeiss photomicroscope fitted with phase-contrast optics.

Electron microscopy. Shadow-casting of air-dried cells with $\mathrm{Pt} / \mathrm{C}$ was done with Balzers BAF 300 at an angle of $35^{\circ}$. Electron micrographs were taken with a Philips EM 300 on Kodak electron microscope film no. 4489.

Optimal growth. The optimal growth conditions of the strains were determined by varying the $\mathrm{NaCl}$ concentration and $\mathrm{pH}$ of the medium and by incubating the cultures at different temperatures. The growth response to $\mathrm{pH}$ values from 4 to 9 was tested. Unless otherwise stated, the buffers Glycyl/glycine $(20 \mathrm{mM})$ for the $\mathrm{pH}$ range 4-5, MES $(20 \mathrm{mM})$ for $\mathrm{pH} 5 \cdot 5-6.5$ and PIPES $(20 \mathrm{mM})$ for $\mathrm{pH} 7-9$ were used. The $\mathrm{pH}$ buffer was adjusted at $20^{\circ} \mathrm{C}$. The $\Delta \mathrm{pK}_{\mathrm{a}} / \Delta T$ (change of $\mathrm{pK}_{\mathrm{a}}$ with temperature) values for Glycyl/glycine, MES and PIPES are $-0 \cdot 025,-0.011$ and -0.0085 , respectively (Stoll \& Blanchard, 1990).

Growth of the strains was determined by counting cells in a Thoma chamber (depth $0.02 \mathrm{~mm}$ ) under a phase-contrast microscope (Zeiss standard 16).

Determination of growth requirements. Unless otherwise indicated, individual carbon sources were added at a final concentration of $0 \cdot 2 \%$ to the mineral medium (half-strength
SME medium without organic compounds) supplemented with $2 \%$ elemental sulfur and $0 \cdot 2 \% \mathrm{NH}_{4} \mathrm{Cl}$. The atmosphere was $\mathrm{H}_{2} / \mathrm{CO}_{2}(80: 20,300 \mathrm{kPa})$ or $\mathrm{N}_{2} / \mathrm{CO}_{2}(80: 20,300 \mathrm{kPa})$.

The ability of strains to utilize alternate electron acceptors was tested using mineral medium without elemental sulfur and sulfate, but with yeast extract and peptone at a final concentration of $0.01 \%$. The concentration of sodium thiosulfate, sodium sulfite or magnesium sulphate was $20 \mathrm{mM}$. Growth was inspected after an incubation period of $2 \mathrm{~d}, 4 \mathrm{~d}$ and 1 week.

Analysis of DNA G + C content. DNA was isolated using the method described by Hensiek (1992). The DNA was denatured, digested with Nuclease P1 (Zillig et al., 1980) and then analysed for $\mathrm{G}+\mathrm{C}$ content according to the method of Mesbah et al. (1989) using DNA of Escherichia coli strain $\mathrm{K} 12(50 \mathrm{~mol} \% \mathrm{G}+\mathrm{C}$; Sigma) and DNA of phage $\lambda$ (48.9 mol\% G+C; Roche Diagnostics) as standards.

Dot-blot DNA-DNA hybridization. Hybridization analyses were carried out according to the DIG System User's Guide for Filter Hybridization (Boehringer Mannheim). If two DNA's give a hybridization signal under the conditions suggested in the supplier's manual, the corresponding organisms are considered to belong to the same species (Jahnke, 1994)

$16 \mathrm{~S}$ rRNA analyses. PCR was used for the amplification of the 16S rDNA gene as described by Saiki et al. $(1985,1988)$ using the following archaeal primer pairs $(\mathrm{M}=\mathrm{A} / \mathrm{C}, \mathrm{R}=$ $\mathrm{A} / \mathrm{G}, \mathrm{Y}=\mathrm{C} / \mathrm{T}$ ): Arch 21F, 5'-TTCCGGTTGATCCYGCCGGA-3'/Arch 958R, 5'-YCCGGCGTTGAMTCCAATT-3'; Universal 1100F, 5'-AACGAGCGMRACCC-3'/ Universal 1400R, 5'-GACGGGCGGTGTGTRC-3' (DeLong, 1992); CAF545, 5'-TTGAGCTCAAGCTTCCGCGGTAATACCAGCYCCGC-3' /CAR952, 5'-TTTTGGATCCCCGGCGTTGACTCCAATTRARCCG-3' (Hellwig, 1994); EAF545, 5'-TTGAGCTCAAGCTTCCGCGGTAAYACCGRCRGYYC-3' /EAR952, 5'-TTTTGGATCCCCGGCGTTGARTCCAATTRAACCG-3'. The amplified PCR products were sequenced with the ABI Prism Dye Termination Kit (Applied Biosystems) and then electrophoresed using a 373A automated DNA sequencer (Applied Biosystems). The sequence alignments and database searching were done using the HUSAR-Heidelberg Server. The PHYLIP 3.5c package was used to establish the evolutionary distance matrix and the phylogenetic trees (Felsenstein, 1985).

Quantitative DNA hybridization. DNA was isolated by column chromatography using hydroxyapatite, according to the procedure of Cashion et al. (1977). DNA-DNA hybridization was performed according to the procedure of De Ley et al. (1970) using a Gilford System 2600 spectrophotometer equipped with a Gilford 2527-R thermoprogrammer and plotter. The hybridization procedure was modified as described by Huss et al. (1983) and Escara \& Hutton (1980). The renaturation rate was established using the TRANSFER.BAS program described by Jahnke (1992).

\section{RESULTS}

\section{Isolation and morphology}

Half-strength SME medium (Stetter et al., 1983) containing yeast extract, peptone and elemental sulfur in a $\mathrm{H}_{2} / \mathrm{CO}_{2}$ atmosphere $(80: 20,300 \mathrm{kPa})$ was 

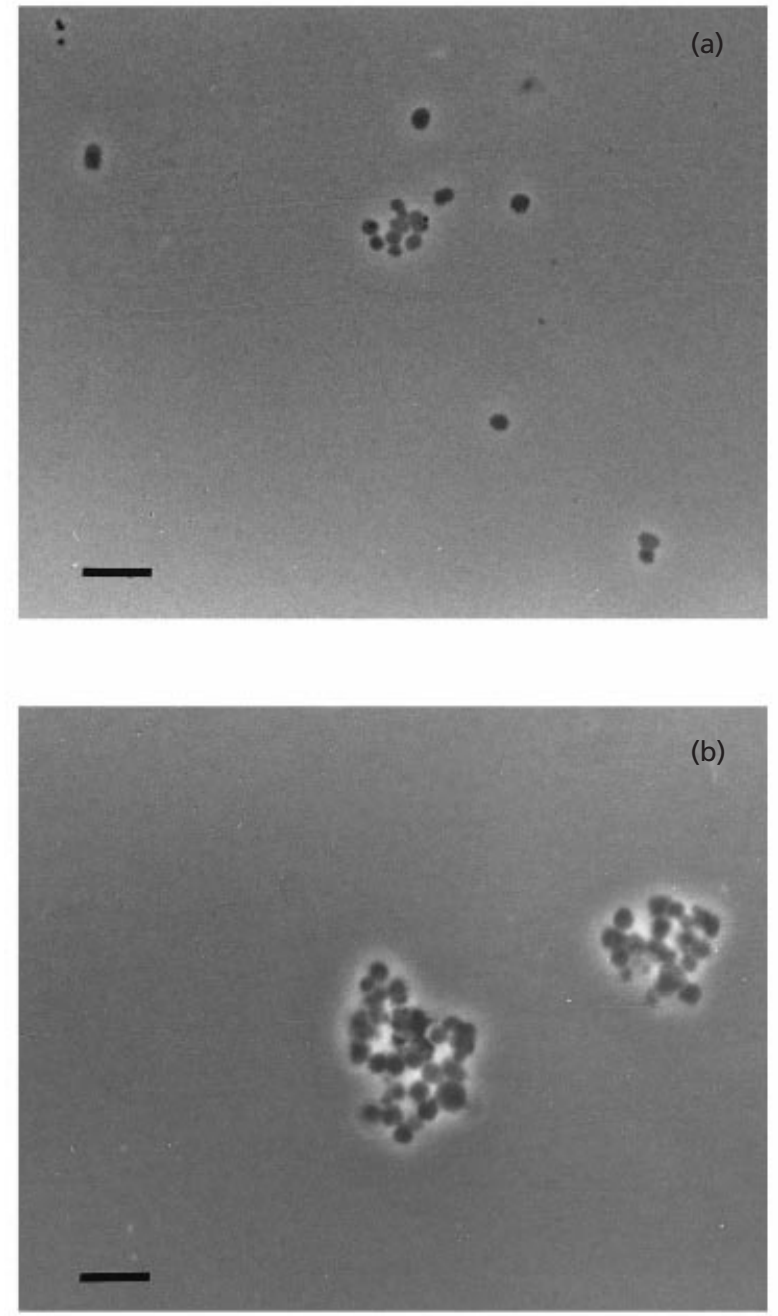

Fig. 1. Light micrographs of Thermococcus aegaeicus (a) and Staphylothermus hellenicus (b). Bars, $5 \mu \mathrm{m}$.

inoculated with $1 \mathrm{ml}$ samples collected from various locations around Palaeochori Bay, Milos, Greece, as described in Methods and incubated at $90{ }^{\circ} \mathrm{C}$. After 1-2 weeks, regular and irregular cocci were observed in the various enrichment cultures. These cultures were transferred successfully and pure cultures were obtained by plating the cultures on half-strength SME medium solidified with Phytagel and alginate. From 36 isolates obtained, 20 were arbitrarily selected for further investigations. Dot-blot DNA-DNA hybridization and partial sequence analysis of $16 \mathrm{~S}$ rRNA suggested that ten isolates were very similar or almost identical to Staphylothermus marinus, three to Pyrococcus woesei, one to Pyrococcus horikoshii and two to Thermococcus celer. Dot-blot DNA-DNA hybridization identified strains $\mathrm{P} 3, \mathrm{P} 5^{\mathrm{T}}, \mathrm{P} 6$ and $\mathrm{P} 8^{\mathrm{T}}$ as not being closely related to the described archaeal species Pyrococcus furiosus, Pyrococcus woesei, Staphylothermus marinus, Pyrodictium occultum and Thermococcus celer. Quantitative DNA-DNA

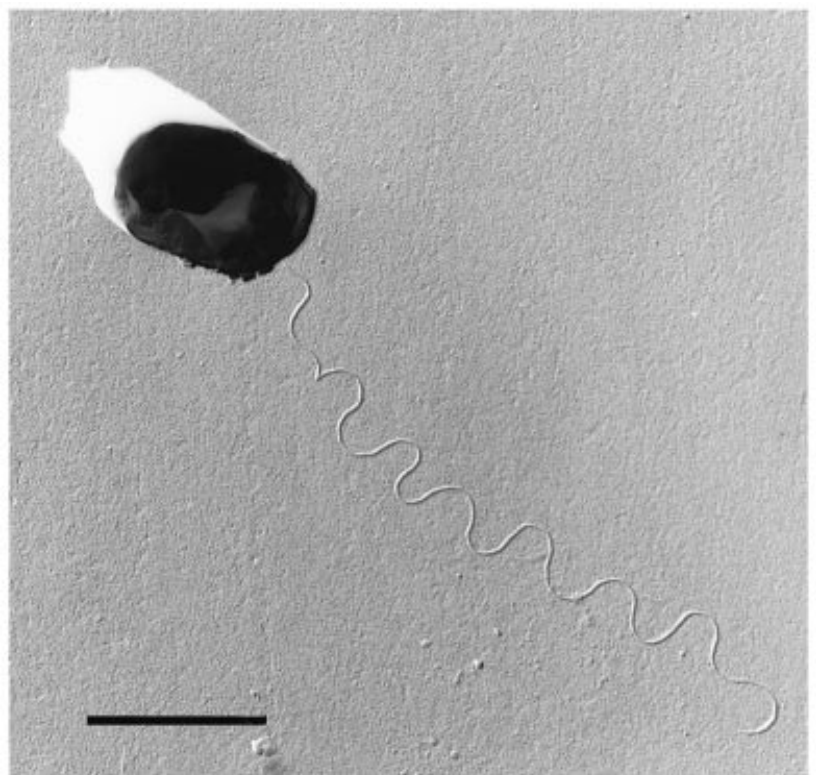

Fig. 2. Electron micrograph of an air-dried and platinumshaded cell of $\mathrm{P5}^{\top}$ showing a single polar flagellum. Bar, $1 \mu \mathrm{m}$.

hybridization revealed that strain $\mathrm{P} 3$ exhibited a DNA hybridization value of $95.2 \%$ with Pyrococcus woesei. Therefore, this strain most likely belongs to this species and was not analysed in more detail. However, two of the isolates, $\mathrm{P}^{\mathrm{T}}$ and $\mathrm{P} 8^{\mathrm{T}}$, were chosen for further analysis and are described in this study as novel species. Strain P6 has also been subjected to further analysis (data not shown). The cells of strain $\mathrm{P} 5^{\mathrm{T}}$ were irregular cocci about $0.8-1.5 \mu \mathrm{m}$ in diameter (Fig. la) with a single flagellum of an extraordinarily short wavelength (Fig. 2). The length of the flagellum was 4-6 $\mu \mathrm{m}$. Cells of $\mathrm{P} 5^{\mathrm{T}}$ could occasionally form aggregates of up to ten cells (Fig. 1a). Cells of strain P8 ${ }^{\mathrm{T}}$ were regular cocci, $0 \cdot 8-1 \cdot 3 \mu \mathrm{m}$ in diameter, often forming large aggregates of up to 50 cells (Fig. 1b). The cells were not flagellated. At room temperature motility of both strains could not be detected by microscopic inspection.

\section{Growth conditions and nutritional requirements for P5 $^{\top}$}

Strain $\mathrm{P}^{\mathrm{T}}$ grew at $\mathrm{pH} 6$ and at an $\mathrm{NaCl}$ concentration of $2.7 \%$ between 50 and $90{ }^{\circ} \mathrm{C}$, with an optimum between 88 and $90^{\circ} \mathrm{C}$. The doubling time at $90^{\circ} \mathrm{C}$ was $1 \cdot 1 \mathrm{~h}$ and the growth yield was up to $10^{9}$ cells $\mathrm{ml}^{-1}$. In large-scale fermentations usually $0.3 \mathrm{~g}$ wet wt $1^{-1}$ was obtained. No growth occurred at 45 or $100{ }^{\circ} \mathrm{C}$. It grew at a temperature of $90^{\circ} \mathrm{C}$ and at an $\mathrm{NaCl}$ concentration of $2.7 \%$ in a $\mathrm{pH}$ range between 4.5 and 7.5 with an optimum around $\mathrm{pH} 6$. The strain grew at between 0.5 and $6.5 \% \mathrm{NaCl}$ with an optimum of $2 \%$. The conditions for the determination of the optimal $\mathrm{NaCl}$ concentration were $90{ }^{\circ} \mathrm{C}, \mathrm{pH}$. The strain is an 

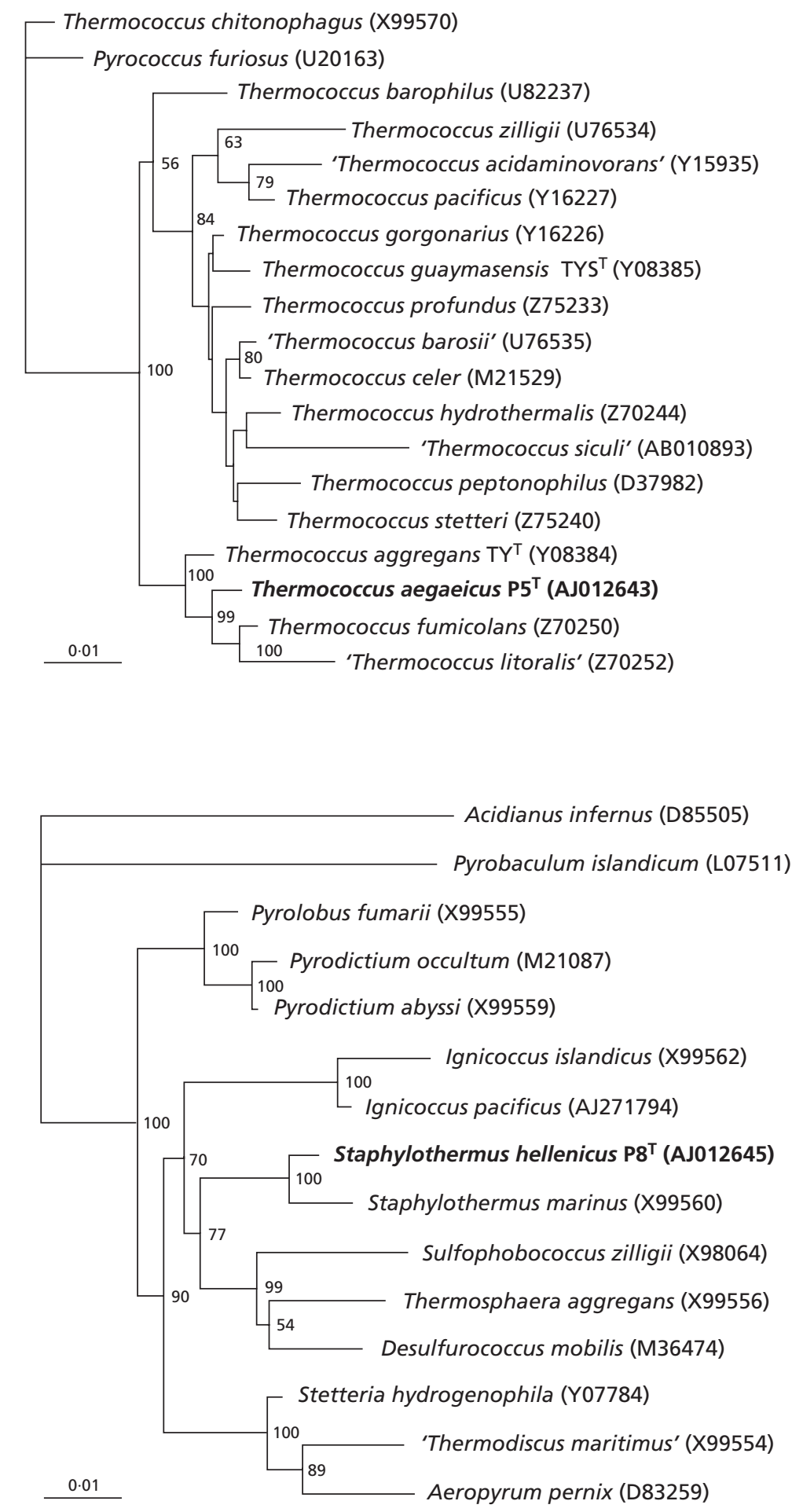

Fig. 3. Unrooted phylogenetic trees based on 16S rRNA sequences analysis showing the relationship of $\mathrm{P}^{\top}$ (Thermococcus aegaeicus) to members of the kingdom Euryarchaeota and representatives of the genus Thermococcus, and of $\mathrm{P}^{\top}$ (Staphylothermus hellenicus) with representatives of the kingdom Crenarchaeota. The distance matrix was calculated using the Kimura method. The trees were constructed using the neighbour-joining method. The scale bar indicates five estimated substitutions per $100 \mathrm{nt}$. The internal numbers indicate absolute bootstrap values per 100 bootstraps performed. obligate heterotroph. Under $\mathrm{H}_{2} / \mathrm{CO}_{2}(80: 20,300 \mathrm{kPa})$ strain $\mathrm{P} 5^{\mathrm{T}}$ grew on yeast extract, peptone or tryptone as carbon sources under $\mathrm{H}_{2} / \mathrm{CO}_{2}$ and $\mathrm{N}_{2} / \mathrm{CO}_{2}$. It was able to utilize starch, but only under $\mathrm{N}_{2} / \mathrm{CO}_{2}$. It was not able to grow in the presence of casein, chitin, pyruvate, cellulose, sodium formate, maltose, glucose, cellobiose, trehalose, ribose, sorbose, sucrose or methanol as sole carbon sources under $\mathrm{H}_{2} / \mathrm{CO}_{2}$ or $\mathrm{N}_{2} / \mathrm{CO}_{2}$.
The same carbon sources were utilized in the absence of sulfur. In a culture medium containing low amounts of yeast extract $(0 \cdot 01 \%)$, elemental sulfur as electron acceptor could not be replaced with sodium thiosulfate, sodium sulfite and magnesium sulphate. Strain $\mathrm{P}^{\mathrm{T}}$ grew in a sulfur-free medium containing $0 \cdot 2 \%$ yeast extract, but its growth was stimulated in the presence of elemental sulfur. The addition of $40 \mathrm{ml}$ air 
to cultures inhibited growth, indicating that the strain is a strict anaerobe.

\section{Growth conditions and nutritional requirements for P8 $^{\top}$}

Strain $\mathrm{P}^{\mathrm{T}}$ grew at $\mathrm{pH} 6$ and at an $\mathrm{NaCl}$ concentration of $2.7 \%$ between 70 and $90{ }^{\circ} \mathrm{C}$, with an optimum at $85^{\circ} \mathrm{C}$. The doubling time at $85^{\circ} \mathrm{C}$ was $2.9 \mathrm{~h}$ and the growth yield was $2 \times 10^{8}$ cells $\mathrm{ml}^{-1}$. In large-scale fermentations usually about $0 \cdot 25 \mathrm{~g}$ wet wt $1^{-1}$ was obtained. At $85^{\circ} \mathrm{C}$ and at $\mathrm{pH} 6$ growth of the strain was observed between 2 and $8 \% \mathrm{NaCl}$ with an optimum of $4 \%$. No growth was observed at $\mathrm{NaCl}$ concentrations below $2 \%$ or at $8.5 \%$. The $\mathrm{pH}$ range for growth was between 4.5 and 7.5 with an optimum at $\mathrm{pH}$ 6. The conditions for the determination of the $\mathrm{pH}$ optimum were $85^{\circ} \mathrm{C}, 2.7 \% \mathrm{NaCl}$. Strain $\mathrm{P} 8^{\mathrm{T}}$ grew on yeast extract under $\mathrm{H}_{2} / \mathrm{CO}_{2}$ and $\mathrm{N}_{2} / \mathrm{CO}_{2}$. Poor growth was observed on peptone. No growth occurred in the presence of casein, pyruvate, cellulose, sodium formate, maltose, glucose, cellobiose, trehalose, ribose, sorbose, sucrose or methanol as sole carbon sources under $\mathrm{H}_{2} / \mathrm{CO}_{2}$ or $\mathrm{N}_{2} / \mathrm{CO}_{2}$. The growth of $\mathrm{P}^{\mathrm{T}}$ was absolutely dependent upon the presence of elemental sulfur. The addition of $20 \mathrm{ml}$ air to the head space of $120 \mathrm{ml}$ serum bottles used for cultivation inhibited growth, indicating that the strain is a strict anaerobe.

\section{$\mathbf{G}+\mathbf{C}$ content}

Strain $\mathrm{P} 5^{\mathrm{T}}$ exhibited a $\mathrm{G}+\mathrm{C}$ content of $45.5 \mathrm{~mol} \%$, as determined by analysis of mononucleotides after digestion of DNA with Nuclease P1 (Zillig et al., 1980), whereas strain $\mathrm{P}^{\mathrm{T}}{ }^{\mathrm{T}}$ had a $\mathrm{G}+\mathrm{C}$ content of $38.8 \mathrm{~mol} \%$.

\section{S rRNA sequencing and phylogenetic position of the new isolates}

To identify the phylogenetic positions of the new isolates, the 16S rRNA genes of the new strains were amplified and sequenced. The DNA sequences $\left(\mathrm{P}^{\mathrm{T}}\right.$, $\left.1311 \mathrm{nt} ; \mathrm{P}^{\mathrm{T}}, 1363 \mathrm{nt}\right)$ of the $16 \mathrm{~S}$ rRNA gene were aligned with those of archaea and then compared in a phylogenetic tree (Fig. 3) based on distance matrix methods (Olsen, 1987). The resulting tree was tested using bootstrap analysis (Felsenstein, 1985).

Strain $\mathrm{P}^{\mathrm{T}}$ was related to the genus Thermococcus. Thermococcus aggregans (Canganella et al., 1998) (99.2\% similarity) and Thermococcus fumicolans (Godfroy et al., 1997) (99\% similarity) were the closest relatives. Strain $\mathrm{P}^{\mathrm{T}}$ was closely related to Staphylothermus marinus $(99 \cdot 3 \%$ similarity). The bootstrap analysis confirmed the relationships between the strains isolated and reference species of the domain Archaea. Strain $\mathrm{P} 5^{\mathrm{T}}$ was associated with Thermococcus aggregans in all of the 100 bootstrap trees tested and Thermococcus fumicolans in 99 of 100 (Fig. 2). Strain $\mathrm{P}^{\mathrm{T}}$ was related to Staphylothermus marinus in all of the 100 bootstrap trees tested (Fig. 3). This strain has
$98 \%$ similarity to Staphylothermus marinus, 95\% similarity to Desulfurococcus mobilis (Huber \& Stetter, 1982) and $81 \%$ similarity to strain $P 5^{\mathrm{T}}$.

\section{DNA-DNA hybridization}

In dot-blot DNA-DNA hybridization experiments at $70 \%$ homology, strain $\mathrm{P}^{\mathrm{T}}$ showed a weak signal with Pyrococcus woesei (Zillig et al., 1987) and therefore it seemed to be related to the genus Pyrococcus. Strain $\mathrm{P}^{\mathrm{T}}$ showed a hybridization signal only with two other isolates from Milos (P2 and P4; data not shown) and strain $\mathrm{P} 8^{\mathrm{T}}$ showed a weak hybridization signal with Staphylothermus marinus (data not shown).

To investigate the relationship of strains $\mathrm{P}^{\mathrm{T}}$ and $\mathrm{P} 8^{\mathrm{T}}$ to their closest relatives in more detail, a quantitative DNA-DNA hybridization of strain $\mathrm{P}^{\mathrm{T}}$ with Thermococcus aggregans and Thermococcus fumicolans, and of strain $\mathrm{P}^{\mathrm{T}}$ with Staphylothermus marinus was performed. $\mathrm{P} 5^{\mathrm{T}}$ exhibited hybridization values of $47 \%$ with Thermococcus aggregans and $38.5 \%$ with Thermococcus fumicolans. Strain $\mathrm{P} 8^{\mathrm{T}}$ showed a hybridization value of $37.5 \%$ with Staphylothermus marinus.

\section{DISCUSSION}

We report here the isolation and characterization of two hyperthermophiles, $\mathrm{P} 5^{\mathrm{T}}$ and $\mathrm{P} 8^{\mathrm{T}}$, belonging to the phylogenetic domain Archaea (Woese et al., 1990).

Strain $\mathrm{P}^{\mathrm{T}}$ is an irregular coccus. Sequence analyses of the $16 \mathrm{~S}$ rRNA gene place $\mathrm{P} 5^{\mathrm{T}}$ in the kingdom Euryarchaeota and the order Thermococcales (Fig. 3) that contains the genera Thermococcus and Pyrococcus. Dot-blot and quantitative DNA hybridization show that members of the genus Thermococcus are the closest relatives of $\mathrm{P}^{\mathrm{T}}$. This is consistent with physiological characteristics, e.g. an optimal growth temperature below $90{ }^{\circ} \mathrm{C}$ typical for members of the genus Thermococcus, whereas Pyrococcus species grow optimally at temperatures higher than $90^{\circ} \mathrm{C}$ and are able to grow at temperatures higher than $100{ }^{\circ} \mathrm{C}$ (Fiala \& Stetter, 1986; Zillig, 1989; Godfroy et al., 1997; Canganella et al., 1998). The members of the genus Thermococcus can be divided into two groups based on their DNA $\mathrm{G}+\mathrm{C}$ content. One group contains species with high $\mathrm{G}+\mathrm{C}$ values $(50-60 \mathrm{~mol} \%)$ and the other group contains six described species listed in Table 1. DNA-DNA hybridization showed that Thermococcus aggregans and Thermococcus fumicolans were the closest relatives of $\mathrm{P}^{\mathrm{T}}$. DNA-DNA hybridization with these species revealed that the hybridization values were lower than $70 \%$, indicating that $\mathrm{P} 5^{\mathrm{T}}$ is a new and distinct species in accordance with the recommendations of the committee on reconciliation of approaches to bacterial systematics (Wayne et al., 1987). Some physiological characteristics discriminate $\mathrm{P} 5^{\mathrm{T}}$ from Thermococcus aggregans and Thermococcus fumicolans and from the Thermococcus species with low $\mathrm{G}+\mathrm{C}$ content (Table 1). The ability of this organism to utilize starch 
Table 1. Phenotypic features distinguishing Thermococcus aegaeicus from its closest relatives, Thermococcus aggregans and Thermococcus fumicolans, and from described Thermococcus species with a low $\mathrm{G}+\mathrm{C}$ content

Data were taken from Marteinsson et al. (1999), Dirmeier et al. (1998), Canganella et al. (1998), Godfroy et al. (1996), Huber et al. (1995), Keller et al. (1995) and Neuner et al. (1990). ND, Not determined.

\begin{tabular}{|c|c|c|c|c|c|c|c|}
\hline \multirow[t]{2}{*}{ Strain } & \multirow{2}{*}{$\begin{array}{c}G+C \text { content } \\
\quad(\mathrm{mol} \%)\end{array}$} & \multicolumn{4}{|c|}{ Utilization of: } & \multirow{2}{*}{ pH optimum } & \multirow{2}{*}{$\begin{array}{l}\mathrm{NaCl} \text { concentration } \\
\text { range for growth }(\%)\end{array}$} \\
\hline & & Maltose & Starch & Casein & $\begin{array}{c}\text { Malt } \\
\text { extract }\end{array}$ & & \\
\hline Thermococcus aggregans & 42 & + & + & + & ND & 7 & $1-3$ \\
\hline Thermococcus fumicolans & 55 & + & - & - & + & 8 & $1.3-2.6$ \\
\hline Thermococcus aegaeicus & 45 & - & + & - & - & 6 & $0.5-6.5$ \\
\hline Thermococcus barophilus & 37 & - & - & + & ND & 7 & $1-4$ \\
\hline Thermococcus chitonophagus & 46 & - & ND & ND & ND & 6.7 & $0.8-8$ \\
\hline Thermococcus alcaliphilus & 42 & - & - & + & ND & 9 & $1-6$ \\
\hline 'Thermococcus litoralis' & 38 & - & - & + & ND & 7.2 & $1.8-6.5$ \\
\hline 'Thermococcus acidaminovorans' & 49 & - & - & + & ND & 9 & $1-6$ \\
\hline
\end{tabular}

distinguishes $\mathrm{P}^{\mathrm{T}}$ from all other strains listed in Table 1 except Thermococcus aggregans. It can be distinguished from Thermococcus aggregans and most Thermococcus species with low $\mathrm{G}+\mathrm{C}$ content by its inability to utilize casein. It also shows the lowest $\mathrm{pH}$ optimum of growth in this group. It shares some phenotypic properties with Thermococcus chitonophagus (Table 1) but, in contrast, strain $\mathrm{P}^{\mathrm{T}}$ is unable to utilize chitin as sole carbon source. It can be distinguished from all Thermococcus species listed in Table 1 by its monopolar flagellum (Fig. 2). This property and its $\mathrm{G}+\mathrm{C}$ content of $45 \mathrm{~mol} \%$ discriminate $\mathrm{P}^{\mathrm{T}}$ also from Thermococcus species with a high $\mathrm{G}+\mathrm{C}$ content, which, as well as the Thermococcus species listed in Table 1, show polytrichous flagellation or are not flagellated. For strain $\mathrm{P}^{\mathrm{T}}$ the name Thermococcus aegaeicus sp. nov. is proposed.

Sequence analysis of $16 \mathrm{~S}$ rRNA indicated that $\mathrm{P} 8^{\mathrm{T}}$ belonged to the kingdom Crenarchaeota. It showed the highest sequence similarity to Staphylothermus marinus (Fig. 3). The genera Desulfurococcus, Stetteria and Staphylothermus have been proposed to belong to the family Desulfurococcaceae (Jochimsen et al., 1997). Staphylothermus marinus has been described to form large aggregates, consisting of up to 100 cells (Fiala et al., 1986). Strain $\mathrm{P}^{\mathrm{T}}$ showed a similar morphology (Fig. 1b). The temperature optimum for growth of P8 ${ }^{\mathrm{T}}$ was lower than for Staphylothermus marinus (85 versus $92{ }^{\circ} \mathrm{C}$ ), but $\mathrm{P}^{\mathrm{T}}$ was able to grow at higher $\mathrm{NaCl}$ concentrations $(2-8 \%$ compared to $1-3.5 \% \mathrm{NaCl})$. This property seems to be an adaptation to the high salt concentration encountered in this ecosystem (Dando et al., 2000). Like Staphylothermus marinus, $\mathrm{P}^{\mathrm{T}}$ was able to grow on complex protein substrates like yeast extract and could not utilize carbohydrates as carbon source. However, in contrast to Staphylothermus marinus (Fiala et al., 1986) only poor growth of $\mathrm{P}^{\mathrm{T}}$ on peptone as sole carbon source was observed. The DNA G + C content of $38.8 \mathrm{~mol} \%$ was similar to that of Staphylothermus marinus (35 mol\%), but quantitative DNA-DNA hybridization revealed less than $70 \%$ similarity with Staphylothermus marinus. In view of this result and various physiological properties we propose strain $\mathrm{P}^{\mathrm{T}}$ is classified as a new Staphylothermus species, Staphylothermus hellenicus sp. nov.

\section{Description of Thermococcus aegaeicus sp. nov.}

Thermococcus aegaeicus (ae.gae'i.cus. M.L. adj. aegaeicus of the Aegean Sea, from where the organism was isolated).

Cells are irregular cocci with a diameter of $0 \cdot 8-1 \cdot 5 \mu \mathrm{m}$. Growth occurs between 50 and $95^{\circ} \mathrm{C}$ with an optimum between 88 and $90{ }^{\circ} \mathrm{C}$. Doubling time at $90{ }^{\circ} \mathrm{C}$ is $1.1 \mathrm{~h}$. $\mathrm{pH}$ range of growth is between 4.5 and 7.5 with an optimum around $\mathrm{pH}$ 6. Optimal $\mathrm{NaCl}$ concentration is $2 \%$, but growth is observed up to $6.5 \%$. Obligate anaerobe, utilizing complex organic compounds like yeast extract, peptone and tryptone as carbon source. Starch can be utilized under an $\mathrm{N}_{2} / \mathrm{CO}_{2}$ atmosphere but not under an $\mathrm{H}_{2} / \mathrm{CO}_{2}$ atmosphere. No growth on pyruvate, malt extract, maltose and casein. Elemental sulfur stimulates growth. DNA $\mathrm{G}+\mathrm{C}$ content is $45 \mathrm{~mol} \%$. Sequence comparisons place $\mathrm{P}^{\mathrm{T}}$ in the order Thermococcales; DNA-DNA hybridization indicates that it belongs in the genus Thermococcus. The type strain was isolated from sediments of Palaeochori Bay, Milos, Greece, located at a depth of $4 \mathrm{~m}$. The type strain is $\mathrm{P}^{\mathrm{T}}\left(=\mathrm{DSM} 12767^{\mathrm{T}}=\mathrm{JCM}\right.$ $\left.10828^{\mathrm{T}}\right)$.

\section{Description of Staphylothermus hellenicus sp. nov.}

Staphylothermus hellenicus (hel.le'ni.cus. Gr. adj. hellenikos, M.L. adj. hellenicus Greek, pertaining to Greece, from where the organism was isolated).

Cells are irregular cocci with a diameter of $0 \cdot 8-1 \cdot 3 \mu \mathrm{m}$, often growing in large aggregates. Growth occurs 
between 70 and $90{ }^{\circ} \mathrm{C}$ with an optimum at $85^{\circ} \mathrm{C}$. Doubling time at $85^{\circ} \mathrm{C}$ is about $2.9 \mathrm{~h}$. $\mathrm{pH}$ range of growth is between 4.5 and 7.0 with an optimum around pH 6. Growth occurs between 2 and $8 \% \mathrm{NaCl}$ with an optimum at $4 \%$. Obligate anaerobe. Grows with yeast extract as carbon source, but growth on peptone as carbon source is poor. Growth is absolutely dependent on elemental sulfur. DNA G $+\mathrm{C}$ content is $38 \mathrm{~mol} \%$. Sequence analyses place $\mathrm{P} 8^{\mathrm{T}}$ in the family Desulfurococcaceae; DNA-DNA hybridization indicates that it belongs in the genus Staphylothermus. The type strain was isolated from a geothermally heated sediment at Palaeochori Bay, Milos, Greece located at a depth of $9 \cdot 4 \mathrm{~m}$. The type strain is $\mathrm{P}^{\mathrm{T}}\left(=\mathrm{DSM} 12710^{\mathrm{T}}=\mathrm{JCM}\right.$ $\left.10830^{\mathrm{T}}\right)$.

\section{ACKNOWLEDGEMENTS}

The authors are grateful to the Max-Planck-Institute of Marine Microbiology (Bremen, Germany), Dr Paul Dando (School of Ocean Science, University of Wales), Dr P. Linke (Geomar Kiel) and Dr H. Schlesner (Institut für Allgemeine Mikrobiologie, University of Kiel, Germany) who provided us with water and sediment samples from Palaeochori Bay. We thank Professor S. Varnavas (Department of Geology, University of Patras, Greece) for logistic support and Professor E. Stackebrandt (DSMZ, Braunschweig, Germany) for examining the phylogenetic position of $\mathrm{P}^{\mathrm{T}}$ and $\mathrm{P}^{\mathrm{T}}$. We also thank H. Preidel (Institut für Allgemeine Mikrobiologie) for large-scale cultivation and Uta Wehmeyer (Institut für Allgemeine Mikrobiologie) for excellent technical assistance. This study was supported by EC Mast contract MAS3-CT95-0021 and the Fonds der Chemischen Industrie.

\section{REFERENCES}

Balch, W. E., Fox, G. E., Magnum, L. J., Woese, C. R. \& Wolfe, R. S. (1979). Methanogens: Re-evaluation of a unique biological group, Microbiol Rev 43, 260-296.

Canganella, F., Jones, W. J., Gambacorta, A. \& Antranikian, G. (1998). Thermococcus guaymasensis sp. nov. and Thermococcus aggregans sp. nov., two novel thermophilic archaea isolated from the Guaymas Basin hydrothermal vent site, Int J Syst Bacteriol 48, 1181-1185.

Cashion, P., Holder-Franklin, M. A., McCully, J. \& Franklin, M. (1977). A rapid method for base ratio determination of bacterial DNA, Anal Biochem 81, 461-466.

Dando, P. R., Hughes, J. A., Leahy, Y., Niven, S. J., Taylor, L. J. \& Smith, C. (1995). Gas venting rates from submarine hydrothermal areas around the island of Milos, Hell Volcanic Arch Continent Shelf Res 15, 913-929.

Dando, P. R., Aliani, S., Arab, H. \& 22 other authors (2000). Hydrothermal studies in the Aegean Sea. Phys Chem Earth 25, $1-8$.

De Ley, J., Cattoi, H. \& Reynaers, A. (1970). The quantitative measurement of DNA hybridization from renaturation rates, Eur J Biochem 12, 133-142.

DeLong, E. F. (1992). Archaea in coastal marine environments, Proc Natl Acad Sci USA 89, 5685-5689.

Dirmeier, R., Keller, M., Hafenbradl, D., Braun, F.-J., Rachel, R., Burggraf, S. \& Stetter, K. O. (1998). Thermococcus acidamino- vorans sp. nov., a new hyperthermophilic alkalophilic archaeon growing on amino acids, Extremophiles 2, 109-114.

Escara, J.F. \& Hutton, J. R. (1980). Thermal stability and renaturation of DNA in dimethylsulphoxide solutions: acceleration of renaturation rate, Biopolymers 19, 1313-1327.

Felsenstein, J. (1985). Confidence limits on phylogenies: an approach using the bootstrap, Evolution 39, 783-791.

Fiala, G. \& Stetter, K. O. (1986). Pyrococcus furiosus sp. nov., represents a new genus of marine heterotrophic archaebacteria growing optimally at $100^{\circ} \mathrm{C}$, Arch Microbiol 145, 56-61.

Fiala, G., Stetter, K. O., Jannasch, H. W., Langworthy, T. A. \& Madon, J. (1986). Staphylothermus marinus sp. nov. represents a novel genus of extremely thermophilic submarine heterotrophic archaebacteria growing up to $98^{\circ} \mathrm{C}$, Syst Appl Microbiol 8, 106-113.

Godfroy, A., Meunier, J.-R., Guezennec, J., Lesongeur, F., Raguenes, G., Rimbault, A. \& Barbier, G. (1996). Thermococcus fumicolans sp. nov., a new hyperthermophilic archaeon isolated from a deep-sea hydrothermal vent in the North Fiji Basin, Int $J$ Syst Bacteriol 46, 1113-1119.

Godfroy, A., Lesongeur, F., Raguénè, G., Quérellou, J., Antoine, E., Meunier, J. R., Guezennec, J. \& Barbier, G. (1997). Thermococcus hydrothermalis sp. nov., a new hyperthermophilic archaeon isolated from a deep-sea hydrothermal vent, Int J Syst Bacteriol 47, 622-626.

Gonzalez, J. M., Masuchi, Y., Robb, F. T., Ammerman, J. W., Maeder, D. L., Yanagibayashi, M., Tamaoka, J. \& Kato, C. (1998). Pyrococcus horikoshii sp. nov., a hyperthermophilic archaeon isolated from a hydrothermal vent at the Okinawa Trough, Extremophiles 2, 123-130.

Hellwig, R. (1994). Untersuchungen zum Nachweis von Archaebakterien in der Ostsee mit Hilfe der PCR-Technologie. Diploma thesis, Universität Kiel, Germany.

Hensiek, R., Krupp, G. \& Stackebrandt, E. (1992). Development of diagnostic oligonucleotide probes for four Lactobacillus species occurring in the intestinal tract, Syst Appl Microbiol 15, 123-128.

Holm, N. G. (1987). Biogenic influences on the geochemistry of certain ferruginous sediments of hydrothermal origin, Chem Geol 63, 45-57.

Huber, G. \& Stetter, K. O. (1992). The order Thermoproteales. In The Prokaryotes, pp. 677-683. Edited by A. Balows, H. G. Trüper, M. Dworkin, W. Harder \& K. H. Schleifer. Berlin: Springer.

Huber, R., Stöhr, J., Hohenhaus, S., Rachel, R., Burggraf, S., Jannasch, H. W. \& Stetter, K. O. (1995). Thermococcus chitonophagus sp. nov., a novel, chitin-degrading, hyperthermophilic archaeum from a deep-sea hydrothermal vent environment. Arch Microbiol 164, 255-264.

Huss, V. A. R., Festl, H. \& Schleifer, K. H. (1983). Studies on the spectrometric determination of DNA hybridization from renaturation rates, J Syst Appl Microbiol 4, 184-192.

Jahnke, K.-D. (1992). Basic computer program for evaluation of spectroscopic DNA renaturation data from Gilford System 2600 spectrometer on a PC/XT/AT type personal computer, $J$ Microbiol Methods 15, 61-73.

Jahnke, K.-D. (1994). A modified method of quantitative colorimetric DNA-DNA hybridization on membrane filters for bacterial identification, J Microbiol Methods 20, 273-288.

Jannasch, H. W., Wirsen, C. O., Molyneux, S. J. \& Langworthy, T. A. (1992). Comparative physiological studies on hyperthermophilic archaea isolated from deep-sea hot vents with 
emphasis on Pyrococcus strain GB-D, Appl Environ Microbiol 58, 3472-3481.

Jochimsen, B., Peinemann-Simon, S., Völker, H., Stüben, D., Botz, R., Stoffers, P., Dando, R. \& Thomm, M. (1997). Stetteria hydrogenophila, gen. nov. and sp. nov., a novel mixotrophic sulfur-dependent crenarchaeote isolated from Milos, Greece, Extremophiles 1, 67-73.

Keller, M., Braun, F.-J., Dirmeier, R., Hafenbradl, D., Burggraf, S., Rachel, R. \& Stetter, K. O. (1995). Thermococcus alcaliphilus sp. nov., a new hyperthermophilic archaeum growing on polysulfide at alkaline pH, Arch Microbiol 164, 390-395.

Kovacs, K. L. \& Rakhely, G. (1996). Plating hyperthermophilic Archaea on solid surface, Anal Biochem 243, 181-183.

Marteinsson, V. T., Birrien, J.-L., Reysenbach, A.-L., Vernet, M., Marie, D., Gambacorta, A., Messner, P., Sleytr, U. \& Prieur, D. (1999). Thermococcus barophilus sp. nov., a new barophilic and hyperthermophilic archaeon isolated under high hydrostatic pressure from a deep-sea hydrothermal vent, Int J Syst Bacteriol 49, 351-359.

Mesbah, M., Premachandran, U. \& Whitman, W. B. (1989). Precise measurement of the $\mathrm{G}+\mathrm{C}$ content of deoxyribonucleic acid by high-performance liquid chromatography, Int J Syst Bacteriol 39, 159-167.

Neuner, A., Jannasch, H. W., Belkin, S. \& Stetter, K. O. (1990). Thermococcus litoralis sp. nov.: a new species of extremely thermophilic marine archaebacteria, Arch Microbiol 153, 205-207.

Olsen, G. J. (1987). The earliest phylogenetic branchings: comparing rDNA-based evolutionary trees inferred with various techniques, Cold Spring Harbor Symp Quant Biol 52, 825-838.

Saiki, R. K., Scharf, S., Faloona, F. A., Mullis, K. B., Horn, G. T., Ehrlich, H. A. \& Arnheim, N. (1985). Enzymatic amplification of $\beta$-globin genomic sequences and restriction sites analysis for diagnosis of sickle anemia, Science 230, 1350-1354.

Saiki, R. K., Gelfand, D. H., Stoffel, S., Scharf, S. J., Higuchi, R., Horn, G. T., Mullis, K. B. \& Ehrlich, H. A. (1988). Primer directed enzymatic amplification of DNA with a thermostable DNA polymerase, Science 239, 487-491.
Stetter, K. O. (1996). Hyperthermophilic prokaryotes, FEMS Microbiol Rev 18, 149-158.

Stetter, K. O., König, H. \& Stackebrandt, E. (1983). Pyrodictium gen. nov., a new genus of submarine disc-shaped sulfur reducing archaebacteria growing optimally at $105^{\circ} \mathrm{C}$, Syst Appl Microbiol 4, 535-551.

Stoll, V. S. \& Blanchard, J. S. (1990). Buffers: principles and practice. In Methods in Enzymology. Guide to Protein Purification, pp. 24-38. Edited by M. P. Deutscher. New York: Academic Press.

Varnavas, S. P. \& Cronan, D. S. (1991). Hydrothermal metallogenic processes off the islands of Nisiros and Kos, Hell Volcanic Arch Mar Geol 99, 109-133.

Varnavas, S. P., Cronan, D. S. \& Anderson, R. K. (1990). Spatial and time series analysis of Santorini hydrothermal waters. In Thera and the Aegean World, vol. 3, pp. 312-324. Edited by D. A. Hardy, C. G. Doumas, J. A. Sakelarakis \& P. M. Warren. London: The Thera Foundation.

Wayne, L. G., Brenner, D. J., Colwell, R. R. \& 9 other authors (1987). International Committee on Systematic Bacteriology. Report of the ad hoc committee on reconciliation of approaches to bacterial systematics. Int J Syst Bacteriol 37, 463-464.

Woese, C. R., Kandler, O. \& Wheelis, M. L. (1990). Towards a natural system of organisms: proposal for the domains Archaea, Bacteria and Eucarya, Proc Natl Acad Sci USA 87, 4576-4579.

Zillig, w. (1989). Section 25. Archaeobacteria. Order I Thermococcales Zillig 1988, $136^{\mathrm{VP}}$. In Bergey's Manual of Systematic Bacteriology, vol. 3, pp. 2236-2237. Edited by J. T. Staley, M. P. Bryant, N. Pfenning \& J. G. Holt. Baltimore: Williams \& Wilkins.

Zillig, W., Stetter, K. O., Wunderl, S., Schulz, W., Priess, H. \& Scholz, I. (1980). The Sulfolobus-'Caldariella' Group: Taxonomy on the basis of the structure of DNA-dependent RNA polymerases, Arch Microbiol 125, 259-269.

Zillig, W., Holz, I., Klenk, H. P., Trent, J., Wunderl, S., Janekovic, D., Erwin, J. \& Haas, B. (1987). Pyrococcus woesei sp. nov., an ultra-thermophilic marine archaebacterium represents a novel order Thermococcales, Syst Appl Microbiol 9, 62-70. 